\title{
Impact of anthelmintic efficacy of Calotropis procera on tegumental enzymes of the trematode, Gastrothylax indicus
}

\author{
Rama Aggarwal ${ }^{1}$, Upma Bagai $^{2}$ \\ ${ }^{1}$ Parasitology Laboratory, Department of Zoology Panjab University, Chandigarh-160014,India. \\ ${ }^{2}$ Parasitology lab, Department of Zoology, Panjab University, Chandigarh-160014,India.
}

\begin{abstract}
The trematode parasite, Gastrothylax indicus was exposed to ethanolic and aqueous flower extract of Calotropis procera to evaluate the anthelmintic efficacy of the plant. The parasites were incubated in 6.25 , $12.5,25,50 \mathrm{mg}$ ethanolic and aqueous extracts per $\mathrm{ml}$ of PBS at a temp of $37 \pm 1^{\circ} \mathrm{C}$. Mortality was observed at $0.5 \pm 0.05 \mathrm{~h}$ and $0.75 \pm 0.10 \mathrm{~h}$ for ethanolic and aqueous extracts respectively for the parasite at the highest test concentration of the plant extract. The commercial anthelmintic albendazole was tested for various concentrations ranged from $20-80 \mu \mathrm{g} / \mathrm{ml}$ and mortality was observed instantly $(0.08 \pm 0.01 \mathrm{~h})$ at the concentration of $80 \mu \mathrm{g} / \mathrm{ml}$. To further investigate the efficacy of plant extract, vital tegumental enzymes of the parasite viz. Alkaline phosphatase (ALP), Acid phosphatase(ACP), Adenosine triphosphatase (ATPase) and Glucose- 6phosphatase (G-6-pase) was found to be suppressed by 43.890, 30.287,18.970 and $22.842 \%$ by ethanolic extract and $62.710,19.780,57.554$ and $10.035 \%$ by aqueous extract whereas albendazole inhibited 41.617 , 25.650, 64.797 and $26.611 \%$ respectively. Enzyme kinetic studies showed inhibition to be non-competitive in case of ACP with both the extracts and albendazole whereas for ALP it was found to be non-competitive with ethanolic and mixed type with aqueous extract. Albendazole showed competitive inhibition in case of ALP.
\end{abstract}

Keywords- Anthelmintic, Calotropis procera, Gastrothylax indicus, Tegumental enzymes

\section{INTRODUCTION}

Helminthic infestation is a major health problem world-wide more particularly in third-world countries because of its prevalence there. However, several serious long-term complications result as after effect of such infection. Thus, iron-deficiency anaemia, malnutrition, dysentry and rectal prolapsed are some of the manifestations of the helminthes like hookworms, Ascaris and Trichuris. Sometimes, helminth-infected persons have been reported to suffer from other infections like tuberculosis, HIV and malaria due to suppression of immune response caused by different helminthes [1]. Gastrothylax indicus (Class: Trematoda) and phylum Platyhelminthes, are responsible for paramphistomosis characterized by acute parasitic gastroenteritis with high morbidity and mortality rates $[2,3,4]$. A number of drugs have been assessed and recommended for the treatment of paramphistomosis [2,5].

Calotropis procera known as aak, is used in ethnoveterinary medicine system as an expectorant, anthelmintic, laxative, purgative, anti-inflammatory and diuretic [6]. Different parts as well as latex of $C$. procera have been reported to have emetic, purgative and anthelmintic effects in traditional medicine [7]. $C$. procera flowers possess good anthelmintic activity against nematodes [6].

Phosphatases are known to play a variety of important roles at the transporting surfaces [8,9], in extracellular digestion and phosphorylation of nutrients transported, secreted and excreted [10]. Due to their presence at the absorptive surfaces, phosphatases react with the substances in the external milieu [9]. Anthelmintics may alter the enzymes and modify the normal metabolism of the absorptive surfaces during their absorption. In this work, the in vitro effect of ethanolic and aqueous extract of $C$. procera and albendazole on phosphatases was studied in Gastrothylax indicus, in order to get a better in sight into the complex enzyme substrate interaction and the mechanism of inhibition of the enzyme by the extracts.

\subsection{Plant material}

\section{MATERIALS AND METHODS}

Flowers of aak (Calotropis procera), were collected from in and around Chandigarh. The plant material was identified in Department of Botany, Panjab University, Chandigarh with Voucher number- 4830.

\subsection{Preparation of extracts}

Flowers of C.procera were washed thoroughly, shade dried and grounded by motor driven grinder into powder form. Both ethanolic and aqueous plant extracts were prepared [6]. Ethanolic flower extract of C.procera (EFECP), was exhaustively extracted by mixing $80 \mathrm{gm}$ of powdered plant material and adding 
approximately $300 \mathrm{ml}$ of ethanol in a soxhlet apparatus. Aqueous extract (AFECP) was prepared by dissolving $100 \mathrm{gm}$ of powdered plant material mixed with $500 \mathrm{ml}$ of distilled water in $1 \mathrm{~L}$ flask and boiled for $4-6 \mathrm{~h}$ in water bath. It was allowed to macerate at room temperature for $24 \mathrm{~h}$ and the brew was filtered through muslin gauze and Whatman filter paper No.1. Both ethanolic and aqueous extracts of plant material were evaporated in Rota evaporator to give crude ethanolic and aqueous extracts. The extracts were scraped off and transferred to screw capped vials at $-4^{\circ} \mathrm{C}$ until used.

\subsection{In vitro experiment}

Worm motility inhibition assay was employed for the evaluation of anthelmintic activity of EFECP and AFECP under in vitro conditions [11]. The in vitro anthelmintic activity was carried out on adult G.indicus worms to determine the inhibitory effect of extracts on adult worms. Mature G. indicus were collected from the rumen of sheep/goat procured from slaughter house. The worms were washed in phosphate buffered saline (PBS $\mathrm{pH7}$.2) and finally suspended in PBS. The study was conducted at four different dilutions of both the extracts viz., $6.25,12.5,25,50, \mathrm{mg} / \mathrm{ml}$ prepared in PBS. The crude aqueous extract was diluted in PBS, whereas, crude ethanolic extract in $1 \%$ DMSO in PBS. Albendazole dissolved in $1 \%$ DMSO and diluted in PBS at concentrations of $20,40,60,80 \mu \mathrm{g} / \mathrm{ml}$ and PBS alone served as postitive and negative control respectively. There were three replicates for each treatment concentration.Immediately after the mortality ,the parasites incubated in $6.25 \mathrm{mg}$ of plant extracts per $\mathrm{ml}$ of PBS were selected for biochemical studies. For albendazole selected concentration was $20 \mu \mathrm{g} / \mathrm{ml}$.

\subsection{Biochemical analysis}

Treated parasites and their respective controls were retrieved from the incubation media at the time when paralysis was seen and were processed for enzymatic analysis. A $10 \%$ homogenate of the enzymes in their respective buffers or $0.25 \mathrm{M}$ sucrose was centrifuged at $5,000 \mathrm{rpm}$ for $25 \mathrm{~min}$ at $0^{\circ} \mathrm{C}$. The supernatant served as source of enzyme activity for different enzyme assays.

\subsubsection{Alkaline phosphatase (ALP) estimation}

The activity of alkaline phosphatase was determined by using p-nitrophenyl phosphate which gets hydrolyzed by action of phosphatase in alkaline $\mathrm{pH}$ to $p$-nitrophenol [12].

$1 \mathrm{ml}$ of buffered substrate $(5.5 \mathrm{mM}$-nitrophenol phosphate in $0.05 \mathrm{M}$ glycine-sodium hydroxide buffer, $\mathrm{pH}$ 10.5) was incubated at $37^{\circ} \mathrm{C}$ for $5 \mathrm{~min}$ to pre equilibrate. After this $0.1 \mathrm{ml}$ of enzyme was added and incubated again for $15 \mathrm{~min}$ at $37^{\circ} \mathrm{C}$. Then $5 \mathrm{ml}$ of $0.085 \mathrm{~N}$ sodium hydroxide was added to stop the reaction and the liberation of p-nitrophenol was measured at $420 \mathrm{~nm} .100 \mu \mathrm{mol} / \mathrm{ml} p$-nitrophenol was used as working standard and the optical density of all the tubes was read at $420 \mathrm{~nm}$ after $10 \mathrm{~min}$

\subsubsection{Acid phosphatase (ACP) estimation}

The activity of acid phosphatase was determined by using p-nitrophenyl phosphate, which gets hydrolyzed by the action of phosphatases in acidic $\mathrm{pH}$ to $p$-nitrophenol [12].

$0.8 \mathrm{ml}$ of buffered substrate $p$-nitrophenyl phosphate was taken in different test tubes. Tubes were incubated for $10 \mathrm{~min}$ to attain a temperature of $37^{\circ} \mathrm{C}$. Thereafter, $0.1 \mathrm{ml}$ of homogenate was added to it and incubated again for $30 \mathrm{~min}$ at $37^{\circ} \mathrm{C}$. Then $5 \mathrm{ml}$ of $0.1 \mathrm{~N}$ sodium hydroxide was added to stop the reaction and the liberation of $p$ nitrophenol was measured. The optical density of all the tubes was read at $420 \mathrm{~nm}$ after $10 \mathrm{~min}$.

\subsubsection{Glucose-6-phosphatase (G-6-pase) estimation}

The enzyme activity was measured in terms of inorganic phosphate formed from incubating medium. To $0.1 \mathrm{ml}$ of homogenate, $0.3 \mathrm{ml}$ of $0.1 \mathrm{M}$ citrate buffer $\mathrm{pH} 6.2,0.5 \mathrm{ml}$ of G-6-Pase and $0.1 \mathrm{ml}$ of distilled water were added. These contents were incubated at $37^{\circ} \mathrm{C}$ for $1 \mathrm{~h}$. Then $10 \mathrm{ml}$ of $10 \%$ TCA was added and the mixture was allowed to stand for $10 \mathrm{~min}$. The mixture was then centrifuged at $2,500 \mathrm{rpm}$ for $10 \mathrm{~min}$. $1 \mathrm{ml}$ of the supernatant after centrifugation was taken and $0.5 \mathrm{ml}$ of acid ammonium molybedate, $0.2 \mathrm{ml}$ of ANSA and $7 \mathrm{ml}$ of distilled water was added to it. This mixture was heated in a boiling water bath, cooled and read at $600 \mathrm{~nm}$ [13].

\subsubsection{Adenosine triphosphate (ATPase) estimation}

The reaction mixture contained $0.2 \mathrm{ml}$ of $0.2 \mathrm{M}$ Tris $\mathrm{HCl}$ buffer $\mathrm{pH} 7.6,0.2 \mathrm{ml}$ of $5 \mathrm{Mm} \mathrm{MgCl}_{2}, 0.2 \mathrm{ml}$ of $10 \%$ homogenate and $0.2 \mathrm{ml}$ of $5 \mathrm{mM}$ ATP solution. The mixture was incubated for $30 \mathrm{~min}$ at $37^{\circ} \mathrm{C} .1 \mathrm{ml}$ of $10 \%$ TCA was added to it and it was allowed to stand for $10 \mathrm{~min}$, centrifuged at 2,500 rpm for $10 \mathrm{~min} .1 \mathrm{ml}$ of supernatant was taken out and $0.5 \mathrm{ml}$ of acid ammonium molybedate, $0.2 \mathrm{ml}$ of ANSA and $7 \mathrm{ml}$ of distilled water was added. The mixture was heated in boiling water bath, cooled and read at $600 \mathrm{~nm}$ [14]. 


\subsubsection{Calculations \\ Activity of Enzyme $=\frac{\text { O.D. of test }- \text { O.D. of blank } \mathrm{x} \text { Vol. of std. } \mathrm{x} \text { Conc. of std. }}{\text { O.D. of std - O.D. of blank } \mathrm{x} \text { Incubation time } \mathrm{x} \text { Protein conc. }}$}

\subsubsection{Specific activity}

Specific activities of the enzymes were expressed as the units of enzymes activity per mg protein. Protein contents of different samples were estimated [15].

\subsubsection{Enzyme kinetic studies}

Vmax (maximum of apparent initial enzyme velocity) and Km (substrate affinity constant) of the ALP and ACP were determined by assaying the enzymes at different substrate concentrations [16]. Similarly, Vmax and $\mathrm{Km}$ of the enzymes were determined of the treated parasite with EFECP and AFECP as a whole and albendazole in vitro system.

\subsubsection{Statistical analysis}

Statistical analysis were carried out by employing Graph pad software 3 and data was expressed as mean \pm S.D. for each group. The statistical significance of inter group difference of various parameters were determined by unpaired student's $t$ test. The comparisons were made between the treated groups and control group of parasites. Exploratory enzyme kinetics was done using Sigma plot 8.0 software and p value $<0.05$ was termed as statistically significant value.

\section{RESULTS}

Following the exposure to different concentrations of the plant extract, the parasites contracted sharply for some time and then went into a relaxed state and continued in the same state till they attained a condition of flaccid paralysis which was followed by death. Table I shows the mortality of worms treated with various concentrations of EFECP, AFECP and albendazole. The controls survived for $9.2 \pm 0.23 \mathrm{~h}$. The treated parasites showed a steady decline in their mortality and survival time with exposure to ascending concentrations of the test dosage. Thus a dose dependent paralytic effect and subsequent loss of motility of the parasite by the extract was evident. Results of enzymatic analysis showing tissue activity, specific activity, percentage inhibition, $p$ value and effect on Vmax and Km due to EFECP, AFECP and albendazole have been summarized in Table II and figs.1-6

In vitro incubation of $G$. indicus with EFECP, AFECP and albendazole inhibited the activity of enzymes. Varying degrees of inhibition was observed with EFECP, AFECP and albendazole. ALP activity was inhibited $43.890 \%$ by EFECP and $62.710 \%$ by AFECP (Table II). EFECP was showing non-competitive inhibition behavior as Vmax got lowered but Km remained unchanged (Fig. 1) whereas AFECP was found to be mixed type inhibitor as both $\mathrm{Km}$ and Vmax got altered (Fig. 2). Inhibition was found to be statistically extremely significant. With albendazole activity of ALP was reduced to $41.617 \%$ (Table II). Inhibition was found to be competitive for ALP (Fig. 3) as Km got increased in the presence of albendazole. ACP activity was reduced to $30.287 \%$ and $19.780 \%$ ( $\mathrm{p}<0.0005$ ) with EFECP and AFECP respectively (Table II). Inhibition was non-competitive in both the extracts as only Vmax got changed (Fig. 4, 5). With albendazole inhibition was found to be $25.650 \%$ (Table II). It was non-competitive in nature as only Vmax got lowered (Fig. 6) and was statistically extremely significant (Table II).

G-6-pase activity was reduced $22.842 \%$ by EFECP and $10.035 \%$ by AFECP. Albendazole showed the inhibition of $26.611 \%$. EFECP and AFECP inhibited the activity of ATP ase by $18.971 \%$ and $57.554 \%$ respectively. Albendazole showed the reduction of $64.797 \%$. Inhibition was found to be extremely significant (TableII).

\section{Discussion}

Different classes of anthelmintics are established to show profound effects on the physical activities, generally culminating into loss of mobility and mortality of helminth parasites in a dose dependent manner $[17,18]$. Following this basic technique several plants/plants parts such as Allium sativun, Zingiber officinale, Curcurbita Mexicana and Ficus religiosa [19], Aretemisia brevifolia [11] Cardiospermum halicacabum [20] Fumaria parviflora [21] have been reported as potent anthelmintics.

The results of the present study showed that $C$. procera flower has good anthelmintic potential. The mortality of the worms (G.indicus) was much faster in albendazole treatment than in EFECP and AFECP. It is in agreement with the findings of earlier workers on different helminth parasites [22,23]. 
Transcuticular diffusion is a common means of entry into helminth parasites for non nutrient and non electrolyte substance in helminth. It has also been shown that this route is predominant for uptake of major broad spectrum anthelmintics; benzimidazole, levamisole and ivermectin by different nematodes, cestodes, and trematode parasites as opposed to oral injestion [24]. In vitro anthelmintic activity of crude extracts of Coriandrum sativum against Haemonchus Contortus was studied and found that hydro-alcoholic extract was better than aqueous extract due to easier transcuticular absorption of hydro-alcoholic extracts into the body of the parasite than aqueous extracts [25].

Tegumental enzymes play a very important role in maintaining the tissue homeostasis within the parasite. Alkaline phosphatase take part in active transport through cellular membranes and acid phosphatase deals with intracellular digestion processes [26,27]. ATPase is known to be related to energy metabolism, active transport and lipid synthesis [28].G-6 Pase presumably has a role in digestion and in absorption of nutrients.

The mode of action of anthelmintics is diverse, reflecting the natural differences in the physiology of the parasite and its potential host. It has been firmly documented that one of the hallmark effects of any anthelmintic is the destruction of the worm's surface. It is due to the fact that the tegumental structures are primary parasitehost interfaces, vital for absorption of nutrients and perception of the surrounding micro environment provided by the host $[29,30,31,18]$.

In the present investigation, enzyme activities in EFECP, AFECP and albendazole treated $G$ indicus were found to be reduced significantly $(\mathrm{p}<0.05)$ compared to the control ones. Other plant extracts such that of Alpinia nigra shoot-extract showed similar effect on ALP, ACP and ATPase activities of Fasciolopsis buski [32]. Inhibition in the activity of G-6 Pase in Trichuris globulosa was shown with ethanolic neem leaf extract [33].

Enzyme kinetic studies showed inhibition to be non competitive in case of ACP with EFECP, AFECP and albendazole whereas for ALP it was found to be non competitive with EFECP and mixed type with AFECP. Non competitive nature of inhibition suggests that substrate binding to the catalytic site of enzyme was not affected. Competitive inhibition of ALP by albendazole shows that inhibitor because of structural similarity compete for the same substrate binding site of the enzyme.

Effect of ethanolic extract of neem leaves on the enzyme kinetics of glycogen phosphorylase, G-6- pase and ATPase in Trichuris globulosa was studied. Non competitive inhibition was reported for glycogen phosphorylase and ATPase whereas it was found to be mixed type for G-6- pase [33].

\section{CONCLUSION}

The effects of the test plant on the motility and survival of the parasite and inhibition caused in the tegumental enzymes clearly indicate that phytochemicals of C.procera flowers may act as potential vermifuge or vermicide. In view of these observations further biochemical studies involving isolated active component (s) of this plant are warranted to confirm its anthelmintic efficacy.

\section{ACKNOWLEDGEMENT}

Dr. Rama Aggarwal is thankful to DST New- Delhi for providing financial assistance for present work.

\section{REFERENCES}

[1] M, Brown, Intestinal helminthes, Medicine, 33(8), 2005, 54-57.

[2] B. Panyarachun, P. Sobhon, Y. Yotsawan Tinikul, C. Chotwiwattanakun, V. Anupunpisit, and P Anuracpreeda, Paramphistomum cervi surface topography of the tegument of adult fluke, Experimental Parasitology, 125, 2010,95-99.

[3] S.S. Lal, A text book of practical zoology invertebrate ( Rastogi Publications, Merrut $9^{\text {th }}$ edn.2006).

[4] J.K. Rhee, C.W. Kang, and H.I. Lee, The karyotape of Paramphistomum explanatum ( Cerplin,1849) obtained from Korean cattle, Korean Journal of Parasitology, 24, 1986, 42-48.

[5] P.P. Rolfe, and J.C. Boray, Chemotherapy of paramphistomosis in sheep, Australian Veterinary Journal, 65(5), 1988, 148-150.

[6] Z. Iqbal, M. Lateef, A. Jabbar, R. Mohammad, and M.N. Khan, Anthelmintic activity of Calotropis procera (Ait) Ait F. flowers in sheep, Journal of Ethnopharmacology, 102, 2005, 256-261.

[7] S.C. Jain, R. Sharma, R. Jain and R.A. Sharma, Antimicrobial activity of Calotropis procera, Fitoterapia, 67, 1996, 275-277.

[8] R. Lumsden, Surface ultrastructure and cytochemistry of parasitic helminthes. Experimental Parasitology, 37, 1975, 267-289.

[9] P.W. Pappas and C.P. Read, Membrane transport in helminth parasites. A review, Experimental Parasitology, 37, 1975, 469-530.

[10] J. Maki, and T. Yanagisawa, Histichemical studies on acid phosphatase of the body wall asnd intestine of adult filarial worms in comparison with that of other parasite nematodes, Journal of Helminthology, 54, 1980, 39-41.

[11] Z. Iqbal, M. Lateef, M. Ashraf, and A. Jabbar, Anthelmintic activity of Artemisia brevifolia in sheep, Journal of Ethnopharmacology, 93, 2004, 265-268.

[12] H.U. Bergmeyer, Methods in Enzymetic Analysis (Academic Press New York, 1963).

[13] M.A. Swanson, Phoser. I Glucose-6-phosphatase. Journal of Biological Chemistry, 184, 1950, 647-659. 
[14] W.W. Kieley, Mg-activated muscle adenosine triphosphatase, in S.P. Collowick and O.N. Kaplan (Eds), Methods in Enzymology,2 (Academic Press New York, 1972), 588-591.

[15] O.H. Lowry, N.J. Rosenbrough, F.N. Farr, and R.J. Rendall, Protein measurement with Folin phenol reagent. Journal of Biological Chemistry, 193, 1951, 265-275.

[16] H. Lineweaver, and D. Burk, The determinants of enzyme dissociation constants. Journal of American Chemical Society, 56, 1934, 658-666.

[17] P. Tippawangkosal, W. Choochote, K. Na-Bangchang, A. Jitpakdi, B. Pitasawat, and D. Riyong, The in vitro effect of albendazole, ivermectin, diethycarbamazine, and their combinations against ineffective third stage larvae of nocturnally subperiodic Brugia malayi ( Narathiwat strain) scanning electron microscopy. Journal of Vector Ecologyu, 29, 2004, 101-108.

[18] S.H. Xiao, J. Guo, J. Chollet, J.T. Wu, M. Tanner, and J. Utzinger, Effect of artemether on Schistosoma mansoni, dose-efficacy relationship, and changes in worm morphology and histopathology. Chinese Journal of Parasitic Diseases, 22, 2004, 148-153.

[19] Z. Iqbal, Q.K. Nadeem, M.N. Khan, M.S. Akhtar, and F.N. Waraich, In vitro anthelminitic activity of Allium sativum, Zingiber officinale, Curcurbita Mexicana and Ficus religiosa. International Journal of Agricultural Biology, 3, 2001, 454-457.

[20] T. Boonmars, W. Khunkitti, P. Sithithaworn, and Y. Fujimaki, In vitro antiparasitic activity of extracts of Cardiospermum halicacabum against third-stage larvae of Strongyloides stercoralis. Parasitology Research,97, 2005, 417-419.

[21] I.R.M. Al-Shaibani, M.S. Phulan, and M. Shiekh, Anthelminitic activity of Fumaria parviflora (Fumariaceae) against gastrointestinal nematodes of sheep. International Journal of Agricultural Biology. 11, 2009, 431-436.

[22] K.A. Tariq, M.Z. Chishti, F. Ahmad, and A.S. Shawl, Anthelmintic efficacy of Achillea millifolium against gastrointestinal nematodes of sheep : in vitro and in vivo studies. Journal of Helminthology, 82, 2008, 227-233.

[23] G.R. Ghangale, M. Tushar, and N.D. Jadhav, In vitro anthelmintic activity of alcoholic extract of Allivum sativum against rumen amphistome, Veterinary World, 2(10), 2009, 385-386.

[24] A.M. Garay, and P.R. Flatt, Insulin releasing and insulin like activity of the traditional antidiabetic plant Coriandrum sativum (Coriander). The British Journal Of Nutrition, 81, 1999, 203-209.

[25] T. Equale, G. Tilahun, A. Debella, A. Feleke, and E. Makonnen, In vitro and in vivo anthelmintic activity of crude extracts of Coriandrum sativum against Haemonchus contortus, Journal of Ethnopharmacology, 110, 2007, 428-433.

[26] C.P. Read, Nutrition of intestinal helminthes, in E.J.L. Soulsby(ed), Biology of Parasites - Emphasis on Veterinary Parasites, (Academic Press New York, 1996) 101-126.

[27] R.D. Lumsden, G. Gonzalez, R.R. Mills, and J.M. Viles, Cytological studies on the absorptive surfaces of cestodes. III. Hydrolysis of phosphate esters. Journal of Parasitology, 54, 1968, 524-535.

[28] A.L. Lehninger, Biochemistry. The molecular basis of cell structure and function, ( Worth Publishers Inc.,New York, 1975).

[29] S. William, S. Botros, M. Ismail, A. Farghally, T.A. Day, and J.L. Bennett, Praziquantel-induced tegumental damage in vitro is diminished in schistosomes derived from praziquantel-resistant infections. Parasitology, 122, 2001, 63-66.

[30] B. McKinstry, I. Fairweather, G. Brennan, and A.B. Forbes, Fasciola hepatica tegumental surface alterations following treatment in vivo and in vitro with nitro xynil (Trodax), Parasitilogy Research, 91, 2003, 251-263.

[31] N. Rivera, F. Ibarra, T. Zepeda, A. Fortoul, R. Hernandez, R. Castillo, and G. Canto, Tegumental surface changes in adult Fasciola hepatica following treatment in vitro and in vivo with an experimental fasciolicide. Parasitology Research, 93, 2004, 283-286.

[32] B. Roy, and A. Swargiary, Anthelmintic efficacy of ethanolic shoot extract of Alpinia nigra on tegumental enzymes of Fasciolopsis buski, a giant intestinal parasite, Journal of Parasitic Diseases, 33, 2009, 48-53.

[33] R. Sarwal, U. Kanwar, and S. Ghandi, IN vitro effect of Neem extract Azadirachta indica on the enzymes of carbohydrate metabolism in Trichuris globulosa (Nematoda), Journal of Parasitic Diseases, 24(2), 2000, 207-208.

Table I. In vitro effect of plant extracts (EFECP, AFECP) and Albendazole on G. indicus

\begin{tabular}{|c|c|c|c|c|}
\hline \multirow{2}{*}{$\begin{array}{c}\text { Dose } \\
\text { Plant extract }(\mathbf{m g} / \mathbf{m l}) \text { / } \\
\text { Albendazole }(\boldsymbol{\mu g} / \mathbf{m l})\end{array}$} & \multicolumn{4}{|c|}{ Time taken in hours for mortality of G.Iindicus } \\
\cline { 2 - 5 } & \multicolumn{4}{|c|}{ INCUBATION MEDIUM } \\
\hline & EFECP & AFECP & ALBENDAZOLE & Control(PBS) \\
\hline \multirow{2}{*}{$6.25 / 20$} & $3.50 \pm 0.18$ & $4.16 \pm 0.35$ & $3.25 \pm 0.12$ & $9.2 \pm 0.23$ \\
\hline $12.5 / 40$ & $2.0 \pm 0.15$ & $2.8 \pm 021$ & $1.50 \pm 0.17$ & \\
\hline $25.0 / 60$ & 0.15 & & & \\
\hline $50.0 / 80$ & $1.0 \pm 0-08$ & $1.5 \pm 0.15$ & $0.50 \pm 0.02$ & \\
\hline & $0.5 \pm 0.08$ & $0.75 \pm 0.10$ & $0.08 \pm 0.01$ & \\
\hline
\end{tabular}

Values are expressed as mean \pm S.D. Each test was done in triplicate.

Table II. Effect of EFECP, AFECP and albendazole on tissue activity (units/g wet wt/min) and specific activity (units/mg protein/min) of ALP, ACP, G-6-pase and ATPase in G. indicus in vitro

\begin{tabular}{|l|l|l|l|l|}
\hline \multirow{2}{*}{$\begin{array}{c}\text { Control/Treatment } \\
\text { PBS/(mg/ml) }\end{array}$} & \multicolumn{1}{|c|}{ ENZYME } & \multicolumn{1}{c|}{ ACTIVITY (Tissue/Specific) } \\
\hline Control & \multicolumn{1}{|c|}{ ALP } & \multicolumn{1}{|c|}{ ACP } & G-6-pase & ATPase \\
\hline & $9.501 \pm 0.157$ & $34.488 \pm 0.306$ & $1.810 \pm 0.010$ & $2.344 \pm 0.020$ \\
& $5.00 \pm 0.083$ & $19.150 \pm 0.162$ & $0.952 \pm 0.005$ & $1.244 \pm 0.011$ \\
\hline & $5.33 \pm 0.09$ & $27.750 \pm 0.025$ & $1.397 \pm 0.010$ & $1.910 \pm 0.017$ \\
\hline
\end{tabular}


Impact of anthelmintic efficacy...

\begin{tabular}{|c|c|c|c|c|}
\hline $\operatorname{EFECP(6.25)~}$ & $2.806 \pm 0.047$ & $13.350 \pm 0.208$ & $0.735 \pm 0.005$ & $1.008 \pm 0.009$ \\
\hline \%Inhibition/p & $43.890 \% / p<0.0001$ & $30.287 \% / p<0.0001$ & $22.842 \% / p<0.0001$ & $18.971 \% / p<0.0001$ \\
\hline Control & $\begin{array}{l}7.761 \pm 0.158 \\
4.084 \pm 0.083\end{array}$ & $\begin{array}{l}34.485 \pm 0.306 \\
18.150 \pm 0.162\end{array}$ & $\begin{array}{l}1.810 \pm 0.010 \\
0.952 \pm 0.005\end{array}$ & $\begin{array}{l}2.760 \pm 0.007 \\
1.456 \pm 0.003\end{array}$ \\
\hline AFECP(6.25) & $\begin{array}{l}2.950 \pm 0.091 \\
1.522 \pm 0.053\end{array}$ & $\begin{array}{l}27.131 \pm 0.00 \\
14.560 \pm 0.030\end{array}$ & $\begin{array}{l}1.620 \pm 0.008 \\
0.857 \pm 0.005\end{array}$ & $\begin{array}{l}1.170 \pm 0.010 \\
0.618 \pm 0.005\end{array}$ \\
\hline $\begin{array}{l}\% \text { Inhibition/p } \\
\text { value }\end{array}$ & $62.710 \% / p<0.0001$ & $19.780 \% / p<0.0001$ & $10.035 \% / p<0.0001$ & $57.554 \% / p<0.0001$ \\
\hline Control & $\begin{array}{l}19.530 \pm 0.249 \\
10.280 \pm 0.127\end{array}$ & $\begin{array}{l}12.249 \pm 0.639 \\
8.440 \pm 0.329\end{array}$ & $\begin{array}{l}1.850 \pm 0.013 \\
0.962 \pm 0.005\end{array}$ & $\begin{array}{l}2.069 \pm 0.005 \\
1.008 \pm 0.003\end{array}$ \\
\hline Albendazole & $\begin{array}{l}11.402 \pm 0.157 \\
6.002 \pm 0.083\end{array}$ & $\begin{array}{l}8.130 \pm 0.336 \\
6.295 \pm 0.169\end{array}$ & $\begin{array}{l}1.340 \pm 0.015 \\
0.705 \pm 0.008\end{array}$ & $\begin{array}{l}0.727 \pm 0.006 \\
0.383 \pm 0.001\end{array}$ \\
\hline $\begin{array}{l}\% \text { Inhibition/p } \\
\text { value }\end{array}$ & $41.617 \% / p<0.001$ & $25.650 \% / p<0.005$ & $26.611 \% / p<0.0001$ & $64.797 \% / p<0.0001$ \\
\hline
\end{tabular}

Values are expressed as mean \pm S.D. Each test was done in triplicate. $(p<0.0005$ extremely significant, $p<0.005$ very significant).

(b)

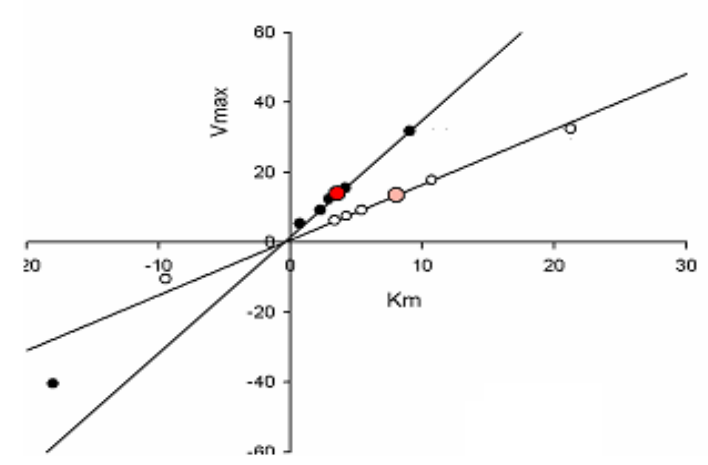

$$
\begin{aligned}
& \mathrm{K}_{\mathrm{m}}(\text { Control, EFECP })=0.833 \\
& \mathrm{~V}_{\max }(\text { Control })=1.5 \\
& \mathrm{~V}_{\max }(\text { EFECP })=0.769
\end{aligned}
$$

(a)

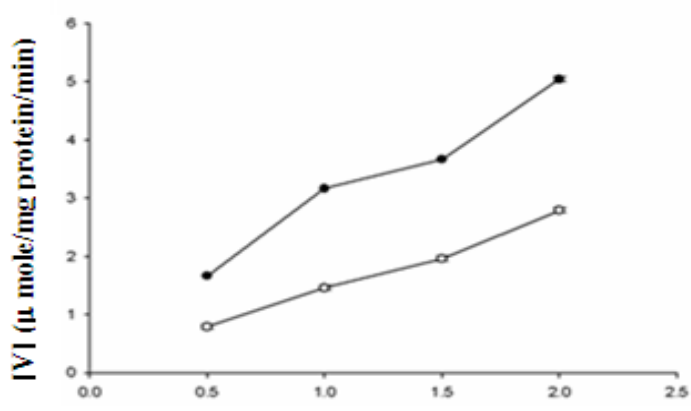

$[\mathrm{S}](\mu \mathrm{M})$

(a)

Figure.1. (a) Michaelis Menten graph shı effect of EFECP on specific activity $[\boldsymbol{V}]$ of ALP taken in units/mg protein/min at differ erı substrate concentration [S] in $\mu$ moles in G. indicus

(b) Lineweaver Burk plot showing maximum apparent initial enzyme velocity in $\mu$ mole/mg protein/min $\left(V_{\max }\right)$ and substrate affinity constant in $\mu \mathrm{M}\left(\mathrm{K}_{\mathrm{m}}\right)$ of ALP in the presence of EFECP in G.indicus. 

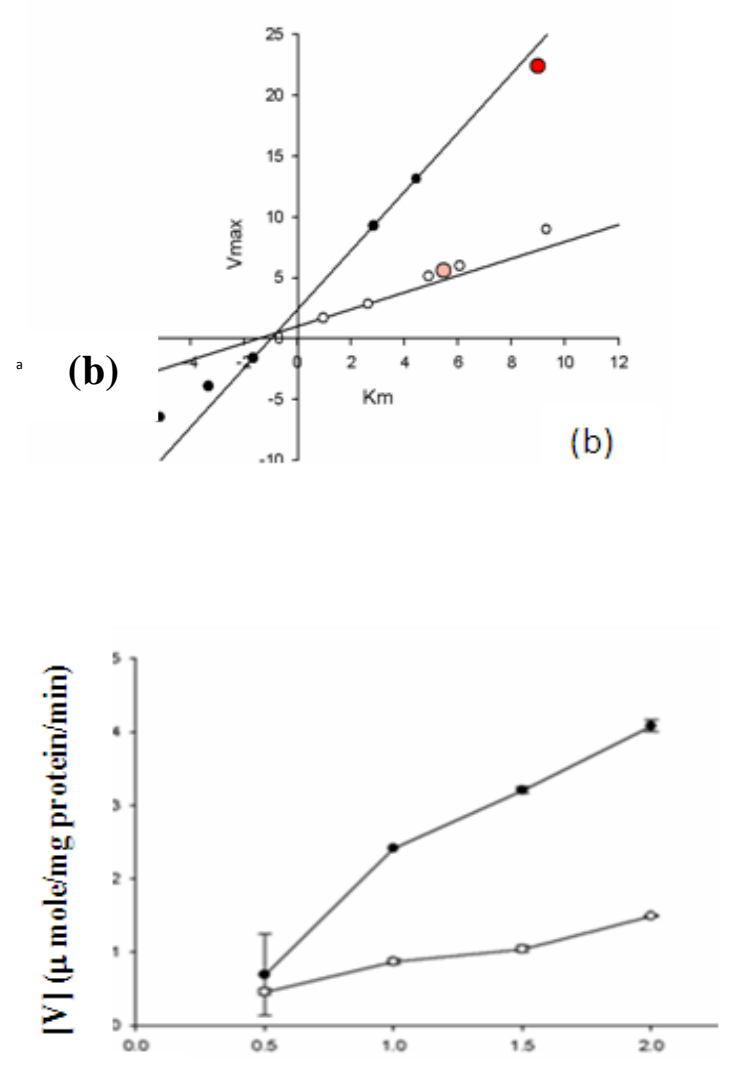

(a)
[S] (uM)

(a)

$$
\mathrm{K}_{\mathrm{m}}(\text { Control })=1.0
$$

$\mathrm{K}_{\mathrm{m}}(\mathrm{AFECP})=1.37$

$\mathrm{V}_{\max }($ Control $)=2.22$

$\mathrm{V}_{\max }(\mathrm{AFECP})=0.833$

Figure.2. (a) Michaelis Menten graph showing ettect of AFECP on specific activity [V] of ALP taken in units/mg protein/min at different substrate concentration [S] in $\mu$ moles in G.indicus.

(b) Lineweaver Burk plot showing maximum apparent initial enzyme velocity $\mu$ mole/mg protein/min $\left(\mathrm{V}_{\max }\right)$ and substrate affinity constant in $\mu \mathrm{M}\left(\mathrm{K}_{\mathrm{m}}\right)$ of ALP in the presence of AFECP in G.indicus 
(b)

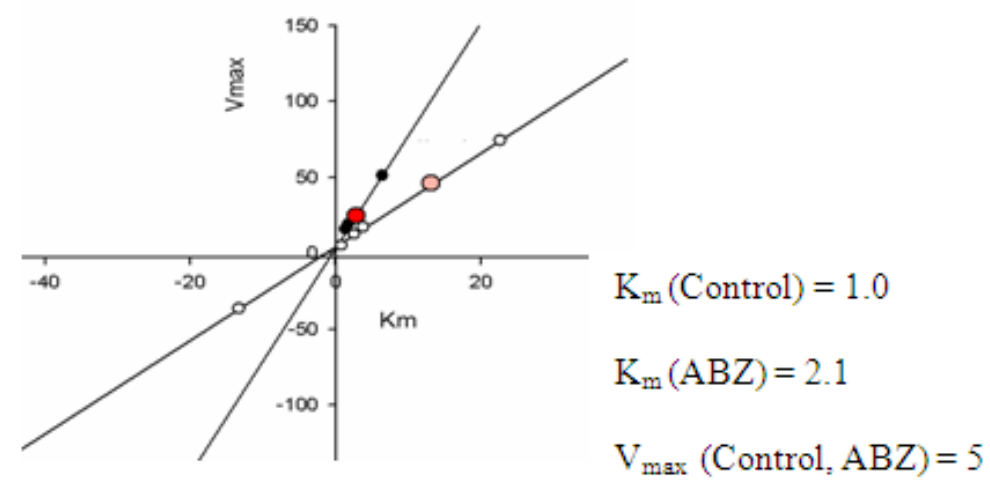

(a)

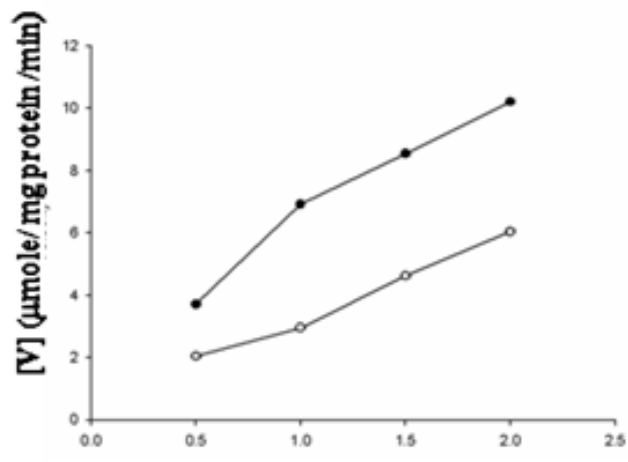

$[\mathrm{S}](\mu \mathrm{M})$

Figure.3. (a) Michaelis Menten graph showing effect of albendazole on specific activity [V] of ALP taken in units $/ \mathrm{mg} /$ protein/min at different substrate concentrations [S] in $\mu$ moles in G. indicus.

(b) Lineweaver Burk plot showing maximum of apparent initial enzyme velocity in $\mu$ mole/ $\mathrm{mg}$ protein/ min $\left(\mathrm{V}_{\max }\right)$ and substrate affinity constant in $\mu \mathrm{M}\left(\mathrm{K}_{\mathrm{m}}\right)$ of ALP in the presence of albendazole in $G$. indicus. 
(b)

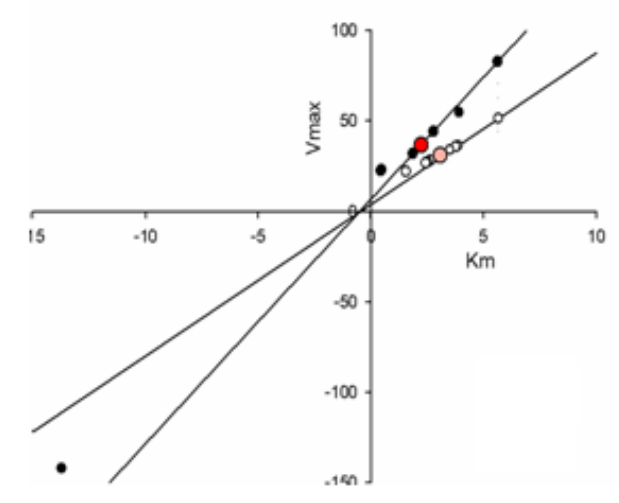

$$
\begin{aligned}
& \mathrm{K}_{\mathrm{m}}(\mathrm{EFECP}, \text { Control })=0.769 \\
& \mathrm{~V}_{\max }(\text { Control })=7.5 \\
& \mathrm{~V}_{\max }(\mathrm{EFECP})=5.0
\end{aligned}
$$

(a)

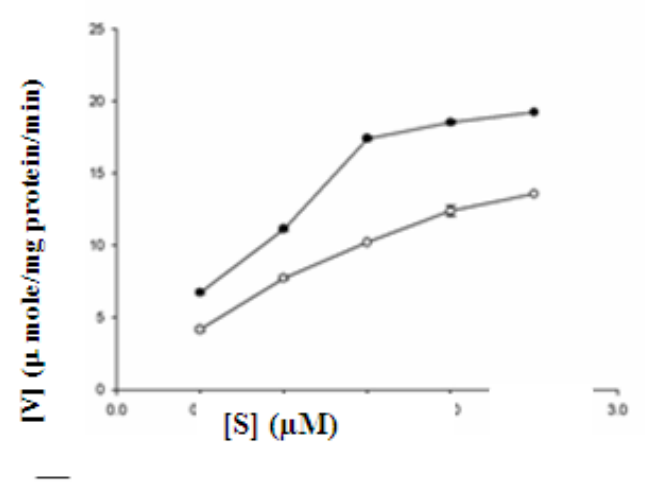

Figure.4. (a) Michaelis Menten graph showing effect of EFECP on specific activity [V] of ACP taken in units/mg protein/min at different substrate concentration $[S]$ in $\mu$ moles in G.indicus.

(b) Lineweaver Burk plot showing max apparent initial enzyme velocity $\mu$ mole/mg protein/min $\left(V_{\max }\right)$ and substrate affinity constant in $\mu \mathrm{M}\left(\mathrm{K}_{\mathrm{m}}\right)$ of $\mathrm{ACP}$ in the presence of EFECP in G.indicus. 


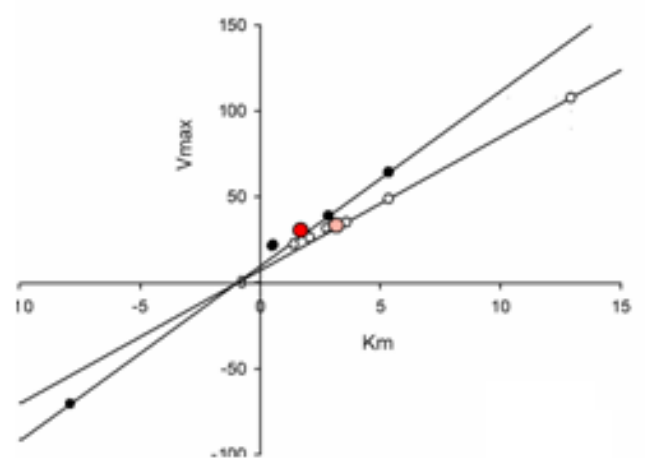

$$
\begin{aligned}
& \mathrm{K}_{\mathrm{m}}(\text { Control, AFECP })=1.17 \\
& \mathrm{~V}_{\max }(\text { Control })=8.335 \\
& \mathrm{~V}_{\max }(\text { AFECP })=6.25
\end{aligned}
$$

\section{(b)}

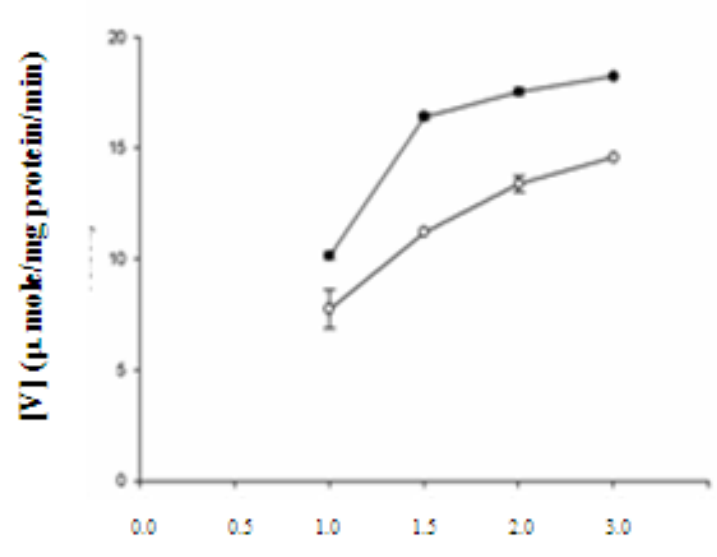

$[\mathrm{S}](\mu \mathrm{M})$

Figure.5. (a) Michaelis Menten graph showing effect of AFECP on specific activity $[V]$ of ACP taken in units/mg protein/min at different substrate concentration $[S]$ in $\mu$ moles in $G$. indicus.

(b) Lineweaver Burk plot showing max apparent initial enzyme velocity $\mu$ mole/ $\mathrm{mg}$ protein/min $\left(V_{\max }\right)$ and substrate affinity constant in $\mu \mathrm{M}\left(\mathrm{K}_{\mathrm{m}}\right)$ of $A C P$ in the presence of AFECP in $G$. indicus. 
(b)

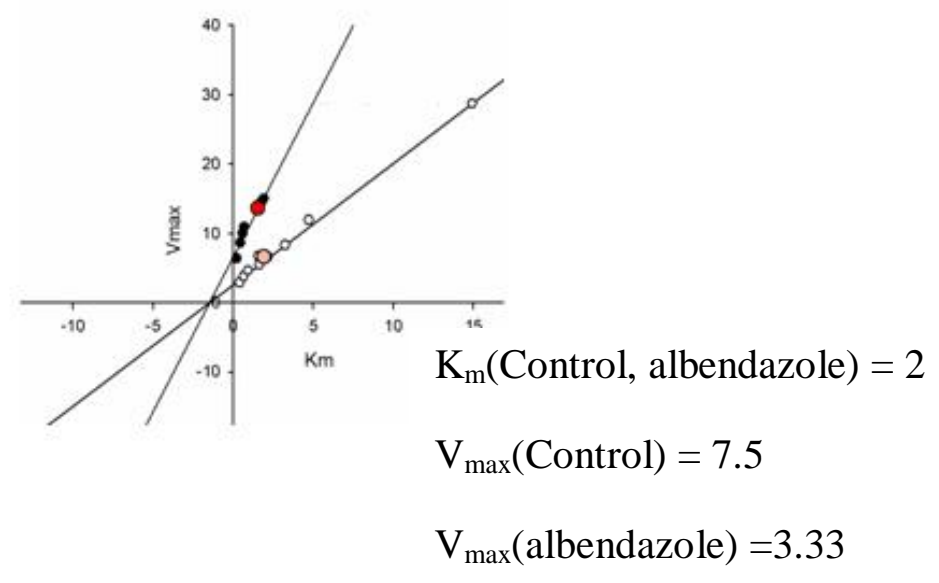

(a)

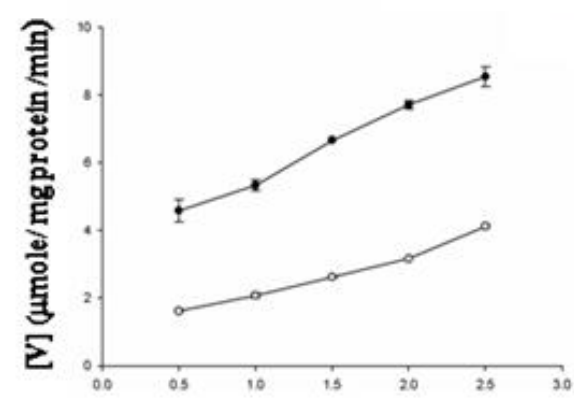

$[\mathrm{S}](\mu \mathrm{M})$

Figure.6. (a) Michaelis Menten graph showing effect of albendazole on specific activity [V] of ACP taken in units/mg protein/min at different substrate concentration [S] in $\mu$ moles in $G$. indicus.

(b) Lineweaver Burk plot showing maximum of apparent initial velocity in $\mu$ mole/ $\mathrm{mg}$ protein/min $\left(\mathrm{V}_{\max }\right)$ and substrate affinity constant in $\mu \mathrm{M}\left(\mathrm{K}_{\mathrm{m}}\right)$ and of ACP in the presence of albendazole in $G$. indicus. 